\title{
Reflections on what year 7 students know and understand about the Holocaust: an argument for empirical research in English primary schools
}

\author{
Rebecca Hale \\ r.hale@ucl.ac.uk \\ UCL Centre for Holocaust Education, UCL Institute of Education, London.
}

\begin{abstract}
This paper presents findings from a subsample of students who participated in a landmark national study to explore knowledge and understanding of the Holocaust in English secondary schools. The students were in year 7 (aged 11-12 years) and indicated they had learned about the Holocaust in primary school but not yet learned about it in secondary school. To date, only a small number of empirical studies have examined Holocaust education in primary schools in England. Consequently, there is a paucity of verifiable evidence about the nature and scale of Holocaust education delivered across the country to this age group. As the findings discussed in this paper were collected from secondary school students there are limitations to the extent that they can attest to this landscape of activities. However, the findings do provide clues about what students know and understand about the Holocaust, influenced - at least in part by time spent learning about the subject in primary school. Thus, this paper seeks to present preliminary insights into primary school Holocaust education in England, highlight the need for further empirical research, and contribute to discourse among educators and academics about if and how the Holocaust should be taught in primary schools.
\end{abstract}

\section{Introduction}

Since 1991, the National Curriculum for history in England has stipulated students in Key Stage 3 (those aged 11 to 14 years) must study the Holocaust. ${ }^{1}$ In practice, not all schools have to implement this mandate, as some 60 per cent of schools in England are academies (publicly funded independent schools) and do not have to follow the National Curriculum. ${ }^{2}$ Even so, successive Westminster governments have continued to highlight the importance of this topic being taught in school and many teachers are committed to teaching this subject. ${ }^{3}$

In England, there is no requirement to teach about the Holocaust at Key Stage 2 (children aged 7 to 11 years), but this does not preclude teachers from doing so. ${ }^{4}$ In one of the few studies conducted in English primary schools, Short and Carrington (1995) found that pupils had discussed the Holocaust with their teachers. ${ }^{5}$ More recently, Foster and colleagues 
(2016) found that 28.5 per cent of young people reported they had first learned about the Holocaust before year 7 when they were in primary school. ${ }^{6}$ This study involved almost 8,000 secondary school students from across England, providing a good indication of the prevalence of Holocaust education in primary schools. Nevertheless, primary school children did not participate and there is a dearth of empirical research in this field, making it difficult to identify the true scale (and nature) of Holocaust education in English primary schools.

Research in other countries has also indicated that Holocaust education is delivered to children in primary/elementary schools. For instance, Paula Cowan and Henry Maitles discussed the Holocaust educational activities of twenty-one primary schools in Scotland ${ }^{7}$ and Simone Schweber conducted a case study of one teacher's approach to Holocaust education in an elementary school in the United States. ${ }^{8}$ Despite this, there remain too few empirical studies in this field, contributing to a myriad of unknowns including: the extent that the Holocaust is part of primary school curricular; how the topic is approached; the knowledge of non-history specialist primary teachers delivering this subject; the impact that learning about the Holocaust has on children (including their emotional, attitudinal and cognitive responses); and consequently, if and/or how it should be taught to children of this age.

Although empirical studies in this area have been limited, commentary from academics and educators has been forthcoming, revealing a number of different stances. These debates encompass considerations that resonate with work done across a number of countries as well as issues that are specific to particular national contexts and frameworks. For instance, Schweber discussed the process of "curriculum creep" occurring in Holocaust education where increasingly younger students encounter this topic at school, facilitated by the availability of books and films. ${ }^{9}$ Of particular concern for teaching in England is the prominence of the film The Boy in the Striped Pyjamas, with 70 per cent of year 7 students reporting that they had watched it. ${ }^{10}$

Those highlighting the merits of teaching about the Holocaust in primary school have argued for its potential to teach children about tolerance and respect for others who are different, learning about the consequences of prejudice, and recognising individual responsibility and accountability. ${ }^{11}$ Researchers from Scotland found that learning about the Holocaust in the final year of primary school can have a positive impact on children's attitudes and values, including more positive attitudes towards refugees. Moreover, attitudinal change continued to hold when children were reassessed in their first year of secondary school. ${ }^{12}$ 
Timetable and curriculum constraints in secondary schools mean there is a risk of Holocaust education being cursory. Even where teachers are able to allocate a number of lessons to Holocaust education, the breadth of topics they could include and the time and attention required for these topics presents a challenge. Accordingly, it has been suggested that foundation work can be done in primary schools. ${ }^{13}$ That said, in light of the paucity of empirical research in primary schools, it is not known what this foundation work should look like or how effective it would be in preparing students for future study of the Holocaust.

Samuel Totten (1999) has disputed the appropriateness of Holocaust education for younger students on a number of grounds including: concern that major concepts would be ignored or simplified (e.g. Christian anti-Semitism, political anti-Semitism and racial antiSemitism); that the historical context would be distorted or ignored (e.g. results of the First World War and Germany's reaction to the Versailles Treaty); the complexities of how people acted would not be considered (e.g. personal and societal pressures); and the true horror of atrocities committed by the Nazis would be concealed to protect children. ${ }^{14}$ Totten argued that teaching about the Holocaust without any of the context limits students' understanding of what happened, however including this in the primary curriculum means that children are exposed to material that they are too young to cope with.

Other educators and academics have highlighted concerns related to this position. For example, Elaine Culbertson cautioned against pedagogical practices which draw on The Diary of Anne Frank without teaching the relevant historiography to students. ${ }^{15}$ This includes ensuring that students understand that hiding was not an option for most Jewish people and learning about what happened to Anne after her last diary entry. Simone Schweber documented the emotional responses of eight year old children learning about the Holocaust for the first time including their distress, shock and dread as they learned about what happened to people at concentration camps. ${ }^{16}$

The concerns expressed by some academics and educators also highlight considerations about how Holocaust education in primary schools could contribute to the formation of misconceptions. Misconceptions have been defined as conceptions that are strongly held, differ from expert conceptions, can hinder effective learning and need to be avoided and/or addressed for students to gain accurate knowledge and understanding. ${ }^{17}$ This is likely to be a concern where material is simplified to make it accessible to younger students. Knowledge acquisition is never a passive process and when a student encounters new 
information they will seek to make sense of it, and this process is likely to incorporate existing frames of references. ${ }^{18}$ Thus, any misconceptions formed during primary school may be resistant to change when students encounter the Holocaust in secondary school because their existing frames of reference colour or distort new information presented to them. Indeed evidence has shown that the core content of secondary students' collective conceptions of the Holocaust were consistent irrespective of whether or not they had been taught about the Holocaust in secondary school. ${ }^{19}$ This suggests that pre-existing conceptions (including muddled ones) are very resistant and can become entrenched by the time students learn about the Holocaust in secondary school. In situations where students have sound knowledge and understanding this is not problematic. However, where this is not the case, the strength of embedded misconceptions, the challenges of addressing them, and the importance of avoiding their formation in the first place need to be confronted.

Undeniably, there are numerous factors outside the classroom that contribute to the acquisition and maintenance of such misconceptions including contemporary representations of the Holocaust and the beliefs of family and friends. In some cases these factors may influence students' thinking long before they encounter the subject in primary school. Moreover, primary school children are typically aged 11 years and below, and this will influence their ability to acquire substantive knowledge and second-order conceptual understanding of the past, especially where the teacher's subject specialism is not history. Consequently, students will have gaps in their knowledge and conceptual frames, making them liable to misunderstand material. Collectively, these issues draw attention to considerations about if and/or how the Holocaust should be taught in primary schools.

It is beyond the scope of this paper to discuss all of the disparate standpoints and research evidence pertaining to Holocaust education in primary schools. The examples provided aim to give some sense of the discourse in this area but it is important to recognise how complicated this field of work is. That said, it has been suggested that positions on the appropriateness of Holocaust education in primary schools can roughly be categorised into three schools of thought. ${ }^{20}$ Firstly, younger children should be protected from learning about the Holocaust because the topic is too complex and traumatic for them. Secondly, while children would not grasp the full complexities of the Holocaust they could learn about it in a simplified format, and thus be more intellectually and emotionally equipped for learning about the full extent of the Holocaust when they are older. Finally, the Holocaust should be taught 
without simplifying the content, with students benefitting from learning about the subject in a structured, informed and sensitive manner, rather than haphazardly from film, television, the Internet or friends

This chapter does not seek to align itself with one particular position. Instead it draws on research conducted by Foster and colleagues, focusing on the survey responses of year 7 students (aged 11-12 years) who indicated that they had learned about the Holocaust in primary school but not yet learned about it in secondary school. The paper aims to explore what this subsample of students knew about the Holocaust and some of the misconceptions they appeared to have.

\section{Method}

In total 7,952 secondary school students aged 11 to 18 years from 74 schools across England completed a survey to explore their knowledge and understanding of the Holocaust. ${ }^{21}$ The majority of the questions were presented in a multiple choice format where students had to select one answer from a number of options. For ease of reading, the answer most appropriate will be referred to as the 'correct' answer. However, Foster and colleagues (2016) emphasised the most appropriate answer for students to select was the one deemed congruent with current historical research and scholarship, recognising that many issues are open to debate. ${ }^{22}$

Students who reported learning about the Holocaust in school were asked to indicate what year group they were in when they had first learned about it. The results showed that 1,603 students had first learned about the subject at primary school. Of these students, 243 of them were in year 7 at the time of completing the survey and also indicated that they had not yet learned about the Holocaust while at secondary school. Thus, for this subsample of students it appeared that their school based learning experiences of the Holocaust had so far only occurred while at primary school.

This survey did not include questions about learning experiences in primary school, and students' learning may have been supplemented by experiences outside of school through books, film, the Internet or conversations with friends and family. Thus, while the findings discussed in this paper give insight into what students know about the Holocaust following from learning about it at primary school, they cannot provide pathways of causation. For 
example, it is not possible to say that students knew particular pieces of information as a direct consequence of if (or how) material was covered in their primary school.

In the subsample of 243 students, 131 (53.9 per cent) were boys and 112 were girls. The majority of students were White and the second largest ethnic group was Asian/Asian British (12.2 per cent.) A small proportion of students (5.9 per cent) identified themselves as Black, African, Caribbean or Black British. The remainder of the students were from Mixed/Multiple ethnic group categories. Given the volume of data that was collected for this study it is not possible to present findings for all survey questions. Instead a selection of findings is presented to give illustrations of students' secure knowledge and areas where knowledge was incorrect. Additionally, the influence of incomplete and/or incorrect knowledge to the formation of misconceptions is discussed.

\section{Findings}

Figure 1 shows the percentage of students who selected the most appropriate answer for the multiple choice questions. Students were most likely to identify the correct answer for 'when did the Holocaust happen?' and 'approximately how many Jews in all of Europe were killed during the Holocaust?' They were less likely to know what percentage of the German population was Jewish in 1933, what happened when the British government found out about the mass murder of Jews, which historical event preceded the mass murder of Jews, or what happened if the military or police refused an instruction to kill Jewish people. 


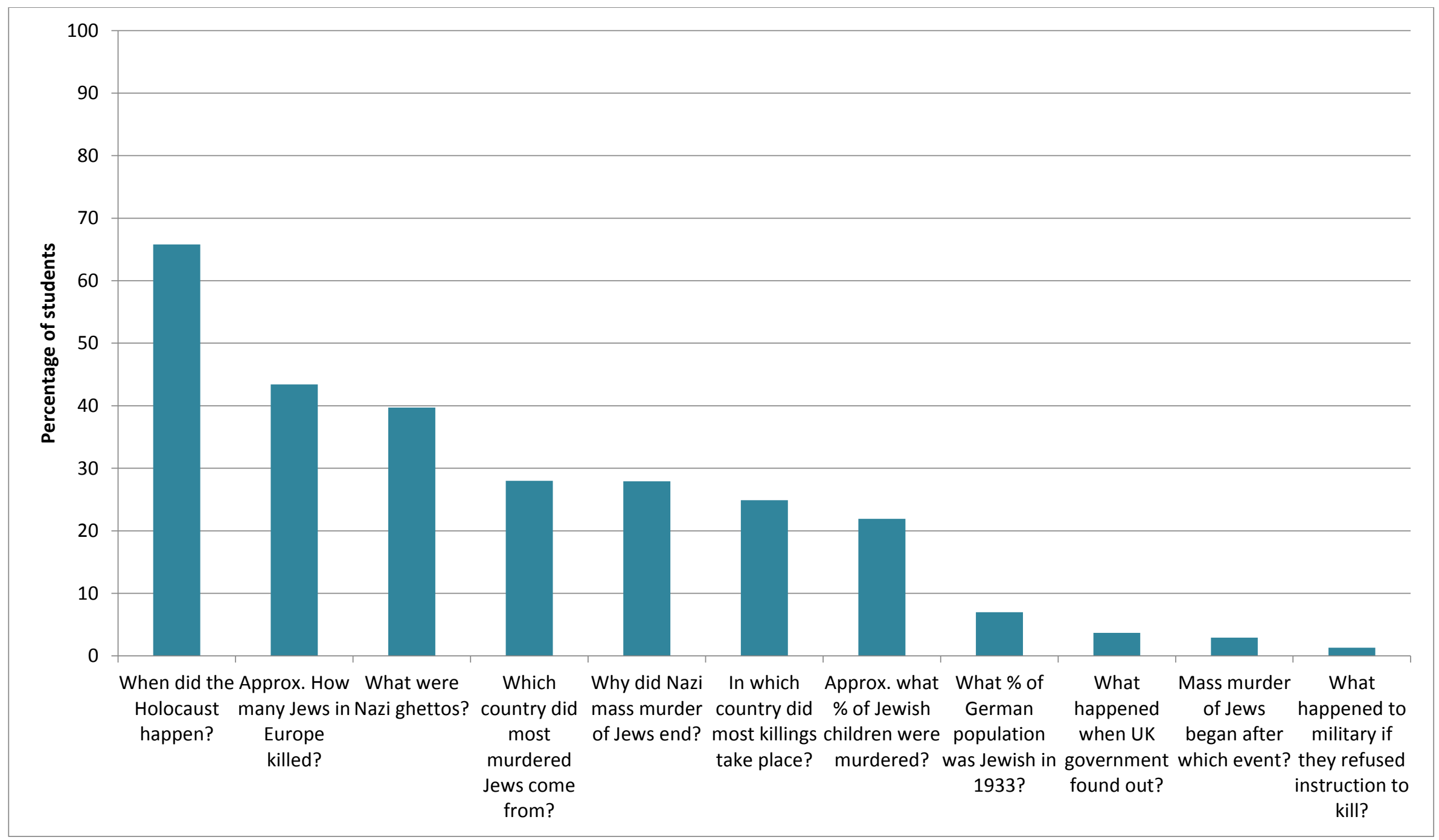

Figure 1: The percentage of year 7 students who answered each question correctly 
Who were the victims?

Students were asked 'who were the victims of the Holocaust?' This was an open question, where students gave their own unmediated responses. The length of responses varied from a single word to several sentences, and they were coded to explore the victim group(s) that students identified. ${ }^{23}$ In the national sample the majority of secondary students gave a relevant answer: 52 per cent of students solely identified Jews/Jewish/Jewish people and 39.7 per cent identified Jews plus at least one other victim group. ${ }^{24}$ In the subsample of students that is under discussion here, 64.2 per cent identified Jews/Jewish/Jewish people and 26.3 per cent identified Jews and at least one other victim group. The other victims groups most frequently identified were homosexuals (12.1 per cent), people with disabilities ( 9.5 per cent) and Roma/Sinti (6.9 per cent). In the national sample, these victim groups were also the most frequently cited. ${ }^{25}$

Figure 1 shows that for the question 'In 1933, what percentage of the German population was Jewish?', only 7 per cent of the year 7 students gave the correct answer (less than 1 per cent were Jewish). Instead, just over a third of students thought that Jewish people accounted for 15 per cent of the German population, and 39.3 per cent of students put the proportion of Jewish people at more than 30 per cent. In these cases where students had overestimated the population, 35.4 per cent were confident in their estimation. A similar trend was found in the national sample; the majority of students overestimated the population and 15.9 per cent of students selected the correct answer.

Students' responses to these questions highlight considerations about what they have learned and how this might relate to the formation of misconceptions. For example, Nazi propaganda sought to drive the belief that Jews were a dominant group in Germany, intent on destroying the country from within. If students have incorrect or incomplete knowledge about the proportion of Jewish people living in Germany in 1933 there is a risk that they will be unable to recognise how deceptive and defamatory this propaganda was, and thus misconceptions may develop. ${ }^{26}$ This was illustrated by the focus group findings of Foster and colleagues, where students who overestimated the pre-war Jewish population were more likely to speculate on the role of a large Jewish population being a causal factor for the Holocaust and thus having a sense that Jews were partly to blame. ${ }^{27}$ Furthermore, as some commentators argue that issues related to prejudice and discrimination can be explored through Holocaust education, then understanding the extent that the Jewish population was in the minority is surely an essential component of students' learning. 
Anti-Semitism is a key concept for any explanation of the Holocaust and it is essential that students understand the form of Nazi anti-Semitism and its genocidal intent towards Jews. ${ }^{28}$ In the survey, students were asked to identify what was meant by the term anti-Semitism, as well as what was meant by the terms racism, homophobia, genocide and Islamophobia to enable comparisons to be made (see Figure 2). Only 16 per cent of the year 7 students knew what anti-Semitism meant and 26.7 per cent knew what genocide was. This compared to 44.9 per cent who correctly identified the meaning of Islamophobia, some three quarters of students who knew what homophobia referred to, and 90.7 per cent who knew what racism was. A similar trend was found in the national sample with 31.8 per cent understanding the meaning of anti-Semitism.

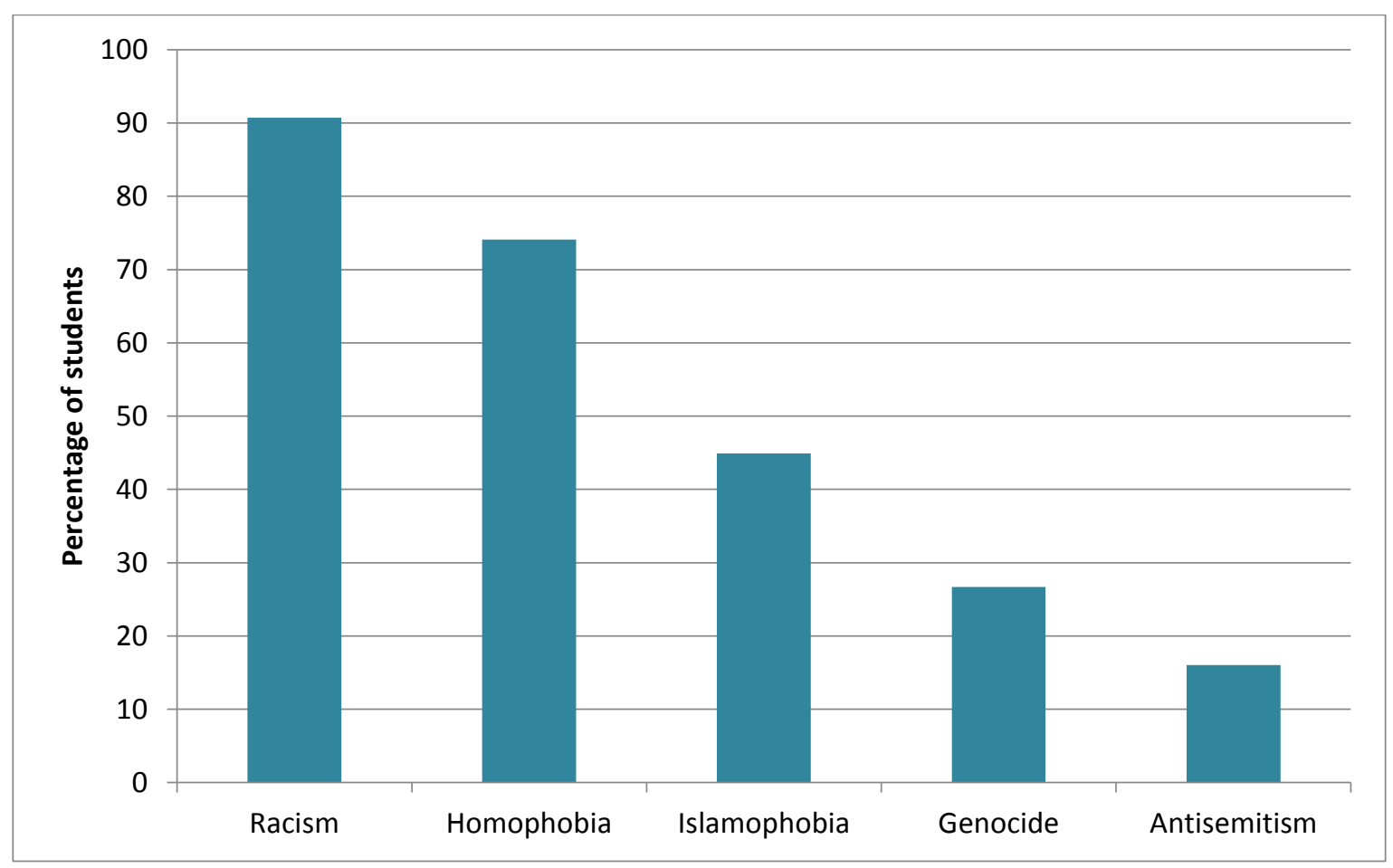

Figure 2: percentage of year 7 students who correctly identified what each term refers to

These findings indicate that understanding important concepts like racism and homophobia is not beyond the capability of young students. Yet what is striking about this data is that students who had learned about the Holocaust in primary school did not understand what was meant by the term anti-Semitism. Given that some educators and academics have argued that primary school Holocaust education could provide a means of teaching about tolerance, respect and the consequences of prejudice and discrimination, then perhaps the very least we should expect students to be able to understand is what anti-Semitism is. This includes being able to identify the term and understand what it refers to. 
This appears to be an ongoing issue. Geoffrey Short and Bruce Carrington found that children aged 10-11 years generally lacked knowledge and understanding of contemporary Judaism. They cautioned that misconceptions about contemporary Judaism could fuel hostility and antiSemitism. ${ }^{29}$ Research conducted by Maitles and colleagues also found that primary school students tended not to know what anti-Semitism was, though the teachers reported their students did understand what anti-Semitism referred to even if they did not recognise the term. ${ }^{30}$ This reminds us that consistent use of the term anti-Semitism is needed in the classroom, as well as learning about the history of anti-Semitism to aid students' understanding of why Jews were targeted, and recognising the totality of the genocidal intent towards Jews.

\section{Who were the perpetrators and who was responsible?}

To explore students' knowledge and understanding of culpability during the Holocaust, they were asked 'who was responsible for the Holocaust?' This was an open question requiring students to give their own answers. The students' answers were coded for their content. ${ }^{31}$ This process revealed that the most frequent relevant response was to ascribe responsibility to Hitler alone (62.2 per cent) with 89.6\% per cent of these students being confident in their answer. Just under a fifth of students $(17.2$ per cent) identified Hitler and the Nazis, and 7.7 per cent of students solely identified the Nazis. In the national sample, there was less attribution to Hitler alone, with 50.7 per cent citing him. A fifth of the national sample identified Hitler with the Nazis and 10.6 per cent said solely the Nazis.

In the survey, students were presented with a list of historical people, places and events and asked to indicate (by responding 'yes', 'no' or 'don't know') whether each person/place/event was connected to the Holocaust. Within this list were: Adolf Eichmann, The SS and Adolf Hitler. The responses of the year 7 subsample are shown in Figure 3. The majority of the subsample identified that Hitler was connected to the Holocaust, but recognition for the other two agents was much lower. In the case of The SS, 22.7 per cent of students said they were connected to the Holocaust, and a similar proportion of students correctly identified that Adolf Eichmann was connected (23.2 per cent). Findings for the national sample were similar for Hitler and Eichmann (91.4 per cent and 23.2 per cent respectively), but differed for recognition of The SS (44.4 per cent).

The students were also asked 'if a member of the military or police refused an instruction to kill Jewish people, what do you think would be most likely to happen to them?' Undoubtedly, this is a complex issue; however the options were created to reflect current historical record and scholarship. Results for the national sample found just 5 per cent of students correctly identified that 
'they would be given another duty instead'. Instead the majority ( 66.5 per cent) said that the military or police would be shot for refusing to obey an order, with two thirds of them saying that they were confident this was the correct answer. A similar pattern emerged for the subsample of year 7 students. As shown in Figure 1, only 1.3 per cent of them selected the correct answer. The majority of the subsample (73.3 per cent) thought that the military and police would be shot and 75.9 per cent indicated they were confident in this answer. Almost a quarter of students (23.8 per cent) thought that the military or police would have been sent to a concentration camp, and of these students 59.7 per cent were confident of this. In sum, most students giving incorrect answers thought they were in fact correct answers (that is, they reported being confident in their answers rather than reporting they did not know the answer and had made a guess). This suggests that by year 7 , these ideas have become accepted and absorbed into students' historical conscientiousness.

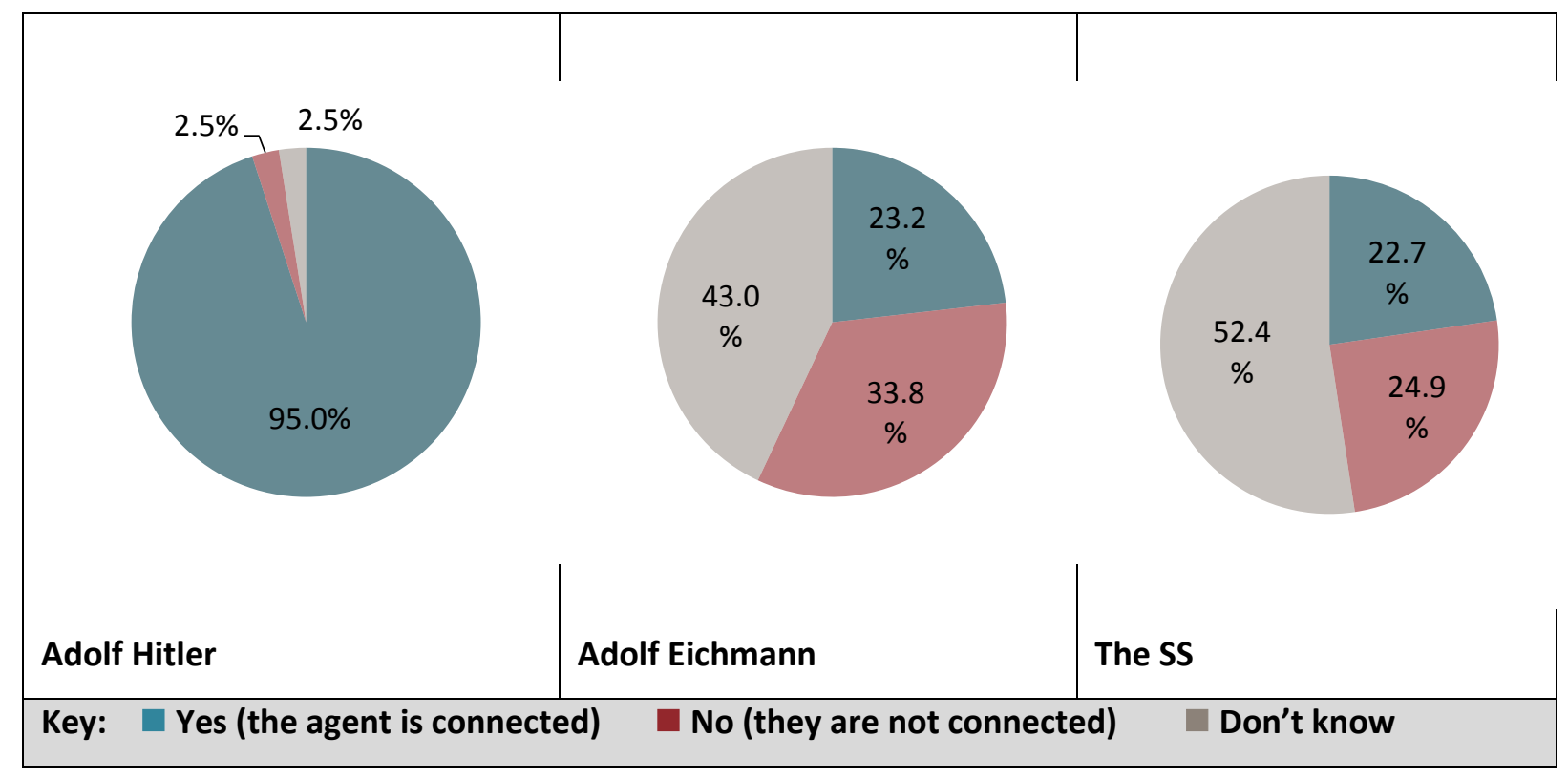

Figure 3: year 7 students' responses to whether each agent was connected to the Holocaust

It is of course noteworthy that some students appeared to have a basic understanding of the perpetrators. Issues surrounding culpability in the Holocaust are complex and it would be unrealistic to expect primary school children to comprehend all of the different agents/agencies and the acts perpetrated. However, these findings suggest a Hitler-centric focus. If primary school students can identify that Adolf Hitler was connected to the Holocaust then it is perhaps reasonable to expect them to have some awareness of the names of other individuals who were involved like Adolf Eichmann. A Hitler-centric view also increases the likelihood that students overlook the role of others and how complicity contributed to the genocide unfolding. Certainly, labelling different individuals, groups and organisations as 'perpetrators', 'collaborators' and 'bystanders' is a simplistic means of categorisation, but it is an important first step in facilitating young people's awareness of 
the nature and complexity of culpability (and the validity of these categories can be discussed with students as their understanding develops). If one of the principal aims of Holocaust education in primary schools is to challenge intolerance, then students need to move beyond ascribing sole responsibility to Hitler and understand the roles of different agents (including the attitudes and actions of German society).

The belief that the police or military would be shot for refusing an order to kill was held with conviction by both primary and secondary students. This misconception is prevalent in public discourse and may account for this belief rather than incomplete information learned at school. Nonetheless, it has detrimental consequences on students' understandings of the Holocaust, especially when educators speak of students 'learning the lessons of the Holocaust' through learning about people's actions at the time. Consideration is also needed for what students learn if they surmise that Nazi perpetrators feared for their lives if they refused to obey an order. Students are likely to become confused and draw erroneous conclusions about accountability, the role of the individual to take responsibility for their actions, the need to confront intolerance and injustice, and the true nature of Nazi perpetrators who chose to kill Jewish people. ${ }^{32}$

\section{When and where did the Holocaust take place?}

Figure 1 shows that the year 7 subsample were most likely to identify the correct answer for the question 'when did the Holocaust happen?' Two thirds of students correctly identified 'the 1940s', although a sizeable proportion (19.8 per cent) opted for the 1920s. As these students reported they had learned about the Holocaust in primary school, this is a surprising finding. In the national sample, Foster and colleagues similarly found that up until year 9 around a fifth of students believed the Holocaust took place in the 1920s, and focus group discussions revealed that even when students identified the 1940s they typically found it difficult to give more accurate chronological detail. $^{33}$

When responding to the questions 'which country did the largest number of Jewish people murdered during the Holocaust come from?' and 'in which country did the largest number of killings of Jewish people actually take place?', students were most likely to identify Germany (48.6 per cent and 65.6 per cent respectively). Of these students almost three quarters were confident in this answer. For both questions approximately a quarter of students identified 'Poland' (that is, Germanoccupied Poland). Thus, the year 7 students lacked secure knowledge in relation to the geographical range of the Holocaust. Given that most students overestimated the size of the pre-war Jewish 
population in Germany, it follows that they also thought that most Jews killed came from Germany. ${ }^{34}$ This demonstrates the centrality of Germany in students' Holocaust consciousness, although we should not overlook the students who did identify (German-occupied) Poland which is encouraging.

It is important for students to know the sequence of relevant events in the pre-war period and the war years, and the significance of these events and how they are related to each other. As the Holocaust developed, its geographical scope also increased across Eastern Europe, and it is important for students to be aware of this so that they recognise it as a continent wide process and not something concerned with Germany alone. ${ }^{35}$

\section{Summary}

These findings provide insights into what year 7 students know about the Holocaust before they learn about it in secondary school, and raise some fundamental concerns about Holocaust education in primary and secondary schools. Students' survey responses indicated that their only school-based experience of learning about the Holocaust had occurred during primary school. However, these students were not specifically asked about primary school learning experiences so the data presented in this paper should be interpreted with caution, especially in relation to any conclusions about the specific topics that primary school teachers appeared to be teaching (or not teaching). Notably, the subject context and amount of time spent learning about the Holocaust is unknown. It is apposite that in Scotland, the primary curriculum includes interdisciplinary studies where individual projects are drawn from a number of subject areas. ${ }^{36}$ It is likely that the Holocaust is taught within this framework and the amount of history covered is unclear. It is probable that the same approach applies to primary school Holocaust education in England, though further research is needed to verify this. Additionally, many primary school teachers are unlikely to have history as their subject specialism. Collectively, these issues will further complicate any attempts to use the data to draw conclusions about the nature of the material covered by teachers in primary schools.

It is inevitable that primary school students would not have extensive knowledge and understanding of the historiography of the Holocaust, and instead this will develop over time. Likewise, the subsample was taken from a dataset of young people aged 11 to 18 years who completed a survey pitched at secondary school students, focusing on Holocaust topics that one would expect teachers to include as part of secondary school curricular rather than a primary school curricular. As Geoffrey Short points out, it is unwise to extrapolate from research with adolescents to the situation in primary schools. ${ }^{37}$ Consequently, the findings presented in this paper are likely to be of particular relevance to secondary school teachers as they begin teaching students about the Holocaust. The similarities in trends between the subsample of year 7 students and the national 
sample could be interpreted in a number of ways, for instance: that primary school Holocaust education may contribute to emergent misconceptions that are resilient to change in secondary school; that secondary Holocaust education needs to improve to build upon what is learned in primary school; or that misconceptions are principally informed by external sources like books and television and will cause issues at both primary and secondary level. It is almost certainly a combination of factors, and therefore the identification of simple pathways of causation is neither feasible nor appropriate.

Nevertheless, that does not detract from the usefulness of the findings to illustrate fundamental considerations about what these students learned in their primary school, especially given their level of conviction on some of the survey questions, and how this could herald misconceptions taking root in their historical consciousness. The wider cultural context also needs to be considered and how contemporary representations of the Holocaust serve to create and/or reinforce misconceptions from an early age. Overall, the findings give insight into students' knowledge when they start learning about the Holocaust, as well as misunderstandings and/or misconceptions that could colour or distort how they interpret new information presented to them in the secondary school classroom. For educators and academics who advocate the introduction of this topic to primary school curricula, thoughtful and critical consideration is needed to determine what should or could be expected from children of this age. Consequently, teaching aims need to clearly show why the Holocaust is being taught and teachers should reflect on whether the issues and skills they want to address could be achieved through other means. ${ }^{38}$

Foster and colleagues' national research revealed that 28.5 per cent of students had first learned about the Holocaust in primary school. Therefore, whether one supports or rejects the notion of Holocaust education for this age group, the reality is that some English primary schools do teach about this subject. The aim of this paper was not to support or contradict particular viewpoints; though the nature of the findings presented (for example, gaps in students' knowledge) do resonate with concerns of simplified and incomplete information being used in primary schools. The findings from Foster and colleagues similarly demonstrated that many secondary school students did not have secure knowledge and understanding of the historiography of the Holocaust. ${ }^{39}$ Consequently, it would appear that irrespective of whether students learn about the Holocaust in primary school or secondary school, there are numerous examples where students are unclear, confused or lack basic knowledge about the subject. However, the findings for the subsample of year 7 students force us to confront some serious and compelling considerations about what is happening in English primary schools, the impact that this is having on students' knowledge and 
understanding, and the influence this exerts on the collective conceptions that some of the youngest students in the school system are formulating.

\section{Acknowledgements}

Sincere thanks are due to the students who took part in this research, and to Dr Andy Pearce for his invaluable feedback when I was writing this paper.

\section{Biography}

Dr Rebecca Hale is a Research Associate at the UCL Centre for Holocaust Education, part of the UCL Institute of Education. She is one of the lead authors of What do students know and understand about the Holocaust? Evidence from English Secondary Schools. She began her career as a secondary school teacher before completing a Masters and PhD in psychology at Keele University. She has worked on a number of research projects in the fields of psychology and education, and has been at UCL since 2013.

\footnotetext{
${ }^{1}$ Gov.uk. Types of School [online]. 2016 [cited 30 September 2016]. Available from: $<$ https://www.gov.uk/types-of-school/academies>

2 Parliament UK. Academies and Free Schools: Key issues for the 2015 Parliament [online]. 2015 [cited 30 September 2016]. Available from: <https://www.parliament.uk/business/publications/research/key-issuesparliament-2015/education/academies-and-free-schools/>

${ }^{3}$ Stuart Foster, Alice Pettigrew, Andy Pearce, Rebecca Hale, Adrian Burgess, Paul Salmons and Ruth-Anne Lenga, What do students know and understand about the Holocaust? (London, 2016) p.203.

${ }^{4}$ Key Stage 1 refers to children aged 5 to 7 years and Key Stage 2 to those aged 7 to 11 years. In England these Key Stages are typically covered while children are in primary school. However, there are several terms used in England to refer to schools attended by children aged 5 to 11 years, including infant school, first school, junior school and primary school. Some children go to middle school when they are 9 years old, some stay at primary school until they are 11 years old and then move to secondary school. In other countries, terms such as elementary school signify schools attended by children under the age of 11 . In this paper, primary school is principally used as a catch-all term to refer to children aged 7 to 11 years.

${ }^{5}$ Geoffrey Short and Bruce Carrington, 'Antisemitism and the primary school: children's perception of Jewish culture and identity', Research in Education, 54 (1995), pp.14-20.

${ }^{6}$ Foster et al., What do students know and understand about the Holocaust?, p.74.

7 Paula Cowan and Henry Maitles, 'Developing positive values: a case study of Holocaust Memorial Day in the primary schools of one local authority in Scotland', Educational Review, 54 (2002), pp.219-29.

${ }^{8}$ Simone Schweber, 'What happened to their pets?: third graders encounter the Holocaust', Teachers College Record, 110 (2008), pp.2073-115.

${ }^{9}$ Ibid., p.2075.

${ }^{10}$ Foster et al., What do students know and understand about the Holocaust?, p.80. For a discussion of issues with The Boy in the Striped Pyjamas see Elaine Culbertson 'A reflection on the use of iconic Holocaust resources' in Samuel Totten and Stephen Feinberg (eds.), Essentials of Holocaust Education: fundamental issues and approaches (New York, 2016), pp.131-35.

${ }^{11}$ Harriet Sepinwall, 'Incorporating Holocaust education into K-4 curriculum and teaching in the United States', Social Studies and the Young Learner, 10 (1999), pp.5-8.

${ }^{12}$ Henry Maitles, Paula Cowan and Eamonn Butler. Never again! Does Holocaust education have an effect on pupils' citizenship values and attitudes? [Online]. 2006 [cited 3 June 2016]. Available from: <http://www.gov.scot/resource/doc/147037/0038530.pdf>

${ }^{13}$ Richard Woolley, Tackling controversial issues in the primary school (Oxon, 2010), p.110.
} 
${ }^{14}$ Samuel Totten, 'Should there be Holocaust education for K-4 students? The answer is no', Social Studies and the Young Learner, 12 (1999), pp.36-39.

${ }^{15}$ Culbertson 'The use of iconic Holocaust resources', p.133-35.

${ }^{16}$ Schweber, 'What happened to their pets', pp.2073-115.

${ }^{17}$ David Hammer, 'More than misconceptions: multiple perspectives on student knowledge and reasoning, and an appropriate role for education research', American Journal of Physics, 63, 10 (1996), p.1316-18.

${ }^{18}$ Foster et al., What do students know and understand about the Holocaust?, p.39.

${ }^{19}$ Ibid., p.60.

${ }^{20}$ Simone Schweber and Debbie Findling, Teaching the Holocaust (Los Angeles, 2007), pp.12-13.

${ }^{21}$ Foster et al., What do students know and understand about the Holocaust?, pp.23-34.

${ }^{22}$ For review of literature pertaining to the multiple choice questions, see Foster et al., What do students know and understand about the Holocaust?

${ }^{23}$ For further information about coding see Foster et al., What do students know and understand about the Holocaust?, p.251.

${ }^{24}$ Foster et al., What do students know and understand about the Holocaust?, p.107.

25 Ibid., p.108.

${ }^{26}$ Ibid., p.126.

${ }^{27} \mathrm{Ibid}$.

${ }^{28}$ Ibid, p.130.

${ }^{29}$ Short and Carrington, 'Antisemitism and the primary school', p.22.

${ }^{30}$ Maitles et al. 'Never again! Does Holocaust education have an effect on pupils' citizenship values and attitudes?', p.26

${ }^{31}$ See Foster et al., What do students know and understand about the Holocaust?, p.251.

32 Ibid., p139-68.

${ }^{33}$ Ibid., p.174.

${ }^{34}$ Ibid., p.191.

${ }^{35}$ Ibid., pp.176-177.

${ }^{36}$ The Scottish Government. Curriculum for Excellence [online] 2008 [cited 25 January 2017]. Available from $<$ http://www.gov.scot/resource/doc/226155/0061245.pdf>

${ }^{37}$ Geoffrey Short 'Holocaust education in primary school: some reflections on an emergent debate', London Review of Education, 1 (2003), pp.119-129.

${ }^{38}$ Woolley, Tackling controversial issues in the primary school, p.110.

${ }^{39}$ Foster et al., What do students know and understand about the Holocaust? 